\title{
EXQ: A Multiple-Item Scale for Assessing Service Experience
}

Dr Philipp Klaus is Professor of Marketing and Sales at ESCEM School of Business and Management, France, Visiting Fellow at Cranfield University School of Management and holds visiting professorships at LUMSA University in Rome, Italy and the University of Valencia in Spain. His areas of expertise include customer experience strategy and management, customer experience quality, marketing strategy, the influence of marketing activities and customer experience on consumer behavior and the financial performance of organizations. He is an experienced senior marketing manager and management consultant with an active, international portfolio of clients over 20 years, ranging from brokering, financial services, business development and change management assignments.

Address: Via Bosii Superiore 4, 17020 Tovo San Giacomo (SV), Italy

Phone: +39 (0) 3498876196

Email: dr.philipp.klaus@gmail.com

Keywords: customer experience quality; service quality; scale development; repurchasing behavior; loyalty.

Dr Stan Maklan is Senior Lecturer at Cranfield University School of Management.

Dr Stan Maklan is an experienced academic, marketer and management consultant with senior, international line management experience in blue chip consumer and business marketing companies. His research interests are: Customer experience, marketing measurement and accountability, customer selection and segmentation and consumer behavior.

\section{Citation:}

Klaus, Ph. and Maklan, S. (2012), “EXQ: A Multiple-item Scale for Assessing Service Experience," Journal of Service Management, Vol. 23, No. 1, pp. 5-33. 


\section{EXQ: A Multiple-Item Scale for Assessing Service Experience}

The well-documented management shift from goods-centered to service-dominant logic (Brodie et al., 2006; Lusch and Vargo, 2006) identifies the differences between marketing services and goods, the latter the traditional domain of marketing scholarship (Shah et al., 2006). This shift exposes the need for companies to deliver high levels of service quality in order to achieve important marketing outcomes: the most important outcomes of service quality identified in the literature are customer satisfaction, loyalty and positive word-ofmouth (Anderson, et al., 1994; Verhoef et al., 2002; Dagger et al., 2007; Kamakura et al., 2002). These outcomes, particularly customer satisfaction, have been demonstrated to generate excess financial returns whilst reducing risk, thus increasing shareholder value and improving market capitalization (Fornell et al., 2006).

In order to manage service quality, firms need to measure it and understand its connection with those important customer outcomes. Assessing the quality of service and its impact on customer behavior has to be measured in an objective way (Parasuraman et al., 1988). SERVQUAL, a multiple-item scale introduced by Parasuraman et al. is the most researched and applied measure of service quality (Buttle, 1996; Morrison Coulthard, 2004). It measures the differences between "consumers' expectations and perceptions of performance of the service they received" (Parasuraman et al., 1988, p.15) in order to "better understand the consumer and, as a result, improve service" (1988, p. 30). Parasuraman et al. (1988) define service quality as a perceived judgment about an entity's overall excellence or superiority, positing service quality as an antecedent of perceived value and hence of outcomes such as purchase.

As services account for an increasing proportion of gross domestic product in developed economies, it has been argued that goods are becoming commoditized and that differentiation is increasingly obtained through service (Reinartz and Ulaga, 2008), although the evidence on this point is mixed (Neely, 2008). A parallel argument particularly prevalent in practitioner literature (Meyer and Schwager, 2007; Schmitt, 1999; Shaw, 2002) states that service, too, is 
increasingly commoditized, and that the contemporary consumer demands more than just competent service, seeking experiences which are "engaging, robust, compelling and memorable" (Gilmore and Pine 2002, p. 10).

This argument, too, is largely conjectural, but increasing academic attention is being paid to whether and how the customer experience might go beyond service (Klaus and Maklan, 2011).

One stream of research identifies experiential factors as a key ingredient in a new construct of service quality and includes emotional factors in the construct of service experience (Edvardsson et al., 2007; Seiders et al., 2005; Lee and Lin, 2005). The work of these scholars is based on the extensive literature applying psychological theories, such as differential emotion theory (Izard, 1997), PANAS (Watson et al., 1988), and PAD model of affect (Mehrabian and Russell, 1974). Marketing researchers explored the importance of these theories for marketing applications successfully. For example, Oliver (1992) applied the differential emotion theory to examine the role of emotions to understand post-purchase satisfaction. PANAS was instrumental in explaining positive and negative affects relating to product and service satisfaction and post-purchase behaviour (Mano and Oliver, 1993; Mooradian and Olver, 1997). Mano and Oliver (1993) examined emotions during consumption in a retail environment using the PAD model of affect. The same theory was useful for capturing the emotional component of consumption experience (Havlena and Holbrook, 1986). Edvardsson et al. (2007), based on these findings, in particular Oliver's (1994) work on the role of emotions in a service setting, (who) concludes that service quality research currently focuses on cognitive dimensions and quality factors linked to service episodes and critical incidents. Researchers argue that there is a need to discuss the service experience through the lens of the customer (Edvardsson et al., 2005) and go beyond a purely cognitive assessment (Edvardsson, 2005). Schembri (2006) posits that customer experience is the key determinant of service quality evaluation and Berry et al. state that "By definition, a good customer experience is good customer service, thus the customer experience is the service" (2006, p.1). 
Another research stream highlights the difference between service quality and service experience by challenging Zeithaml's (1988) definition of service quality as a global assessment. Voss et al. (2008) believe that service quality is focusing largely on transaction specific assessment rather than the notion of the customer journey, described as the customer's sequence of touchpoints with the firm in buying and obtaining service, a prevalent one in service design (Berry et al., 2002; Voss et al., 2008). This notion, while confirming the definition of service quality that the customer's perception may vary as the journey is made (Schembri, 2006), refines its static measurement. Cowley (2008), for example, demonstrates that service encounters may be viewed retrospectively as more positive in order to rationalize a desired repeat purchase. Payne et al. (2008) deliver further evidence that the service experience goes beyond the construct of service quality by observing that the customer journey may both precede the service encounter and continue after it. This is verified by the work of Meyer and Schwager (2007), defining the service experience as customers' internal and subjective response to any direct or indirect contact with the company across multiple touchpoints. Other scholars draw on this work and propose an even further differentiation between service quality and service experience. For example, Payne et al. (2008) create awareness of the fact that the service experience includes communication, usage, as well as the service encounters. Consequently, if it is suggested that customers assess their service experience holistically (Verhoef et al., 2009), corresponding holistic frameworks have been proposed (Grewal et al., 2009; Payne et al., 2008; Verhoef et al., 2009), leading to calls for empirical examinations of the service experience (Verhoef et al., 2009, Voss et al., 2008).

The notion of service experience, and its impact on business, is only now receiving great attention (Prahalad and Ramaswamy, 2004; Johnston and Clark, 2008; Klaus, 2011). Creating superior customer experiences is now seen as a key objective for service organizations (Verhoef et al., 2009) in their efforts to build customer loyalty (Badgett, Moyce and Kleinberger, 2007). Jerry Gregoire, former CIO of Dell, maintains that "the customer experience is the next competitive battleground". Managing the customer experience has become a crucial strategic ingredient for service organizations (Klaus, 2011).

Researchers (e.g. Schembri, 2006) believe that the customers' service experience should be the focus of research as it is the key determinant of consumers' service quality evaluation; "By definition, a good customer experience is good customer service, thus the customer 
experience is the service" (Berry et al., 2006, p.1). A corresponding scale needs to be developed to evaluate the service experience from the customer's point of view (Verhoef et al., 2009). Considering that managing the service experience is a priority for organizations, developing its measure addresses the call for researchers for "working on relevant issues and making a difference in the practice of marketing" (Reibstein, Day and Wind, 2009).

However, to develop the new measure, it is recognized that "scale [development] must go hand-in-hand with conceptual development of the construct [service experience] itself" (Brakus et al., 2009, p. 52). Therefore the measure should be based on a broader and more comprehensive conceptualization (Verhoef et al., 2009) that links the service experience to purchasing behavior. This conceptual model of service experience aims to refine existing conceptual models for customer experience which have been proposed both in conceptual studies (Verhoef et al., 2009) and in studies which elicit the supplier's perception rather than the customer's (Payne et al., 2008; Voss et al., 2008).

This article describes the development and validation of a multiple-item scale for service experience (EXQ) and provides (a) a sought after conceptualization that captures the domains of the construct, (b) a measure from the customers' point of view, and (c) a validation of the psychometric properties of the scale.

The subsequent section summarizes the existing literature on service experience research. Drawing from the literature, we conduct a qualitative study that generates attributes of service experience. The proceeding section describes the purification and validation of a scale and its psychometric properties. The article then validates the scale to generate an empirically founded definition of service experience (EXQ). The final section discusses the limitations of the study, offers directions for future research and discusses managerial implications.

\section{SERVICE EXPERIENCE}


In this section we discuss the key literature relevant to the development of our service experience scale.

\section{Service Experience Research}

Service experience has its roots in many disciplines including economics, psychology, social psychology, management and marketing. Hence, the growing body of knowledge on service experience is somewhat fragmented and lacks a universally accepted way of integrating the different perspectives (Holbrook, 2006).

Over 70 years ago, some economists accepted that the consumer utility function alone is insufficient to explain consumer behavior. Consumer choices are also a function of personal value systems (Parson, 1934) which drive the choice of desired consumer experiences connected with the purchase of goods: goods are purchased to create desired experiences (Keynes, 1936).

Despite acknowledging that customer experience represents a "sufficient choice criteria" (Howard and Sheth, 1969, pp. 26), early consumer behavioral theorists insisted on explaining consumer actions as a purely rational cognitive process (Ajzen and Fishbein, 1977). This view, linking cognition, affect and behavior (CAB), suggests customers are involved in a rational assessment of past, present and their imagined future experiences and use this information to determine their behavioral intentions. According to $\mathrm{CAB}$, customers base their decision process on a sequential rational assessment of expectations versus outcomes (Gronroos, 1997). CAB researchers championed their definition of rational consumer behavior as the leading theory of buying behavior. Predictably, this is challenged by experiential theorists who suggest that consumer behavior is determined by the customer experience, which consists of a rational and an emotional assessment (Hirschmann and Holbrook, 1982). Gentile et al.(2007) expand that view suggesting that the experience includes spiritual, sensorial, physical, rational and emotional elements. 
Researchers have now turned their focus towards the differences in experiences and two streams of literature have emerged, peak experiences and the overall assessment of customer experience. Peak experiences research challenges the notion of the traditional, service quality grounded thinking that the experience is a summation of all the clues towards a total customer experience (Verhoef et al., 2009). Peak experiences research posits that while encountering extraordinary experiences, such as the often-cited river rafting experience (Arnould and Price, 1993), consumers do not assess their experience via the traditional cognitive process such as the confirmation-disconfirmation paradigm (Oliver 1999).

Shifting from the study of the individual, and the individual customer experience, researchers explore how customer experience develops during interactions between companies and consumers, particularly the involvement of the customer experience provider and the customer in designing, delivering and influencing the customer. This literature spans from a provider-driven unidirectional perspective to customer-driven co-created experiences. Scholars suggest that suppliers can, with the support of their customers, carefully craft the delivery of a customer experience. This perspective highlights the role of knowledge sharing processes, as the supplier seeks to understand every facet of the customer experience throughout all direct and indirect service encounters (Frow and Payne, 2007). Furthermore, a temporal aspect of the service experience is added by the literature through the notion of the customer journey (Payne et al., 2008), stating that customer evaluation precedes the service encounter, and continues after it. Building on this notion, Gentile et al. (2007, p. 397) state that: "The customer experience originates from a set of interactions between a customer and a product, a company, or part of its organization, which provoke a reaction. This experience is strictly personal and implies the customer's involvement at different levels (rational, emotional, sensorial, physical and spiritual)."

Co-creating experiences involves interaction between consumer and supplier and, while the literature links these approaches with the customer experience, sometimes the linkage is vague. The co-creation perspective regards the customer experience holistically, including all interactions, in a sequential order. In this framework, every interaction contributes to the customer's evaluation of their experience. The function of the company is to facilitate customers' ability to create an optimal experience (LaSalle and Britton, 2003). A limitation 
of the co-creation framework is its insufficient explanation of the impact of social context on the customer experience, such as peer-to-peer interactions. Although the brand community literature provides useful insights into social aspects of customer experience (Kozinets et al., 2008), research fails to identify how membership in a brand community changes the overall customer experience. Another perspective on social context is to discover the roles of multiple stakeholders asserting that the customer and supplier relationship is only one of many interconnected relationships important in creating customer experience (Flint and Mentzer, 2006).

There is emerging experience practitioner literature that follows work in other disciplines e.g. sociology (Butler, 1990), anthropology (Garfinkel, 1967) and social philosophy (Schatzki, 1996). Most of this literature is focused on either the "entertainment" aspects of the customer experience (Pine and Gilmore, 1999) or on managerial outcomes and actions (Berry, Carbone and Haeckl, 2002). Few investigate the customer experience from a theoretical perspective (Gentile, Spiller and Noci, 2007) in an empirical fashion.

\section{Consequences of Service Experience}

The lack of a coherent conceptualization has not prevented the literature from positing on its consequences. Researchers link service experience to consumer purchasing behavior, either directly via customer loyalty (Haeckel et al., 2003; Mascarenhas et al., 2006; Reichheld, 2003) or indirectly via customer satisfaction (Pullmann and Gross, 2004), recommendations and positive word-of-mouth (Pine and Gilmore, 1998). However, these studies are conceptual and sometimes even anecdotal. Therefore, researchers have not yet operationalized the construct of service experience, or related it to consumer behaviour.

The quality management literature provides a basis for grounding claims about the consequences of service experience empirically. Zeithaml et al. (1996) use the PIMS research (Buzzell and Gale, 1987) to support their view that service quality influences market share and generates premium prices (Phillips et al., 1983). The authors posit a causal chain between 
quality, customer satisfaction, intention, behavior (e.g. loyalty, recommendation) and profitability. If service experience is the new construct for service quality, then we expect it to have similar consequences upon the marketing outcomes that ultimately improve business results.

Therefore, we recapitulate that service experience is an evolving concept. It originates in economics and has been advanced by consumer behavior, psychology, sociology, marketing and managerial practice. The emerging service experience construct is far broader than the limited functional service encounter suggested by current measures. It includes pre and post service encounter experiences, addresses emotional as well as functional dimensions of quality and includes the customer's social context. It includes an assessment of value-in-use, is formed over multiple channels and varies with context (Lemke et al., 2010).

Building on this and the previously cited definitions, and the context of our research, we define service experience as the customer's cognitive and affective assessment of all direct and indirect encounters with the firm relating to their purchasing behavior (1997).

However, we believe that no universally accepted integration of the different perspectives on customer experience exists and the literature review indicates that no single stream, nor each of the streams taken together, have developed a fully realized conceptualization of customer experience. Indeed, the problem of conceptualizing experience is that it is defined so broadly, so "holistically" that it is of little use to managers: scholarship needs to become clearer as to its scope (Maklan and Klaus, 2011).

\section{DEFINITION AND DOMAIN OF EXQ}

To incorporate the wide range of possible assessment of service experience criteria arising from the literature, we use a framework based on the means-end-chain approach (Parasuraman et al., 2005). This framework follows the established approach to explore and validate measures of service quality in different contexts (Parasuraman et al., 2005). The 
theoretical foundation of the framework allows the exploration of the attributes and dimensions of service experience.

We propose that the antecedents of EXQ are specific concrete attributes, which trigger perceptual attributes. The perceptual attributes, i.e. evaluation of the service experience, combine to assess more abstract dimensions. The evaluation of attributes, and the resulting dimensions, generate a higher-order abstraction (e.g. overall assessment of EXQ), which influences behavioral intentions and actual behavior (Zeithaml et al., 2000).

Concrete attributes, also referred to in the literature as the technical aspects of the service experience, are the antecedents that influence this process, while the higher-order abstractions and purchasing behavior are the outcome of the process. Therefore, service-experience influencing features associated with the core evaluation process of the experience will build the dimensions for the EXQ scale. This is particularly pertinent for perceptual attributes which, by their nature, are more experiential than technical. In addition, researchers suggest that perceptual attributes should be chosen over technical aspects because of their ability to capture more enduring evaluative aspects. While technical aspects of the experience will change through, for example, advances in technology, the more abstract perceptual attributes will not change as the focus of evaluation of experience (Parasuraman et al., 2005).

These perceptual attributes, and the resulting dimensions, can be evaluated on a scale, while technical aspects are often judged on an existing or non-existing basis. Therefore, perceptualbased dimensions will not only deliver assessments of particular dimensions, but will also be more specific and capable of delivering greater insight about the parts of the experience that affect outcomes most. The relationship between the processes of evaluating the service experience and its consequences builds a solid underpinning to verify the validity of a construct consisting of perception based attributes such as EXQ (Parasuraman et al., 2005). The links between attributes of service experience and service outcomes (consequences) are means-end chains: the mental connections that link the different levels of knowledge (Reynolds and Gutman, 1988). Numerous studies have shown that research methods based on means-end theory are suitable for a wide range of marketing applications, including customers' evaluation of services, products and experiences (Olson and Reynolds, 2001). 


\section{SCALE DEVELOPMENT}

Our study presents a validated multi-item scale based on the underlying construct of service experience that extends previous research on service experience and service quality measures. The measure is called the service experience scale: 'EXQ'. The research determines its dimensions by analysing that which customers describe as the triggers of their purchasing and re-purchasing behavior. We conduct exploratory research to develop a new multidimensional consumer-based service quality scale based on the customers' service experience. The methodology follows Churchill's (1979) scale development paradigm. As suggested by the literature, and other scale-developing studies (Walsh and Beatty, 2007), the scale will be developed in four stages: scale generation, initial purification, refinement and validation (see Figure 2).

Stage 1 articulates the meaning and domain of service experience based on insights from the literature and a comprehensive qualitative study. It results in a preliminary scale containing 37 items that represent five dimensions.

Stage 2 describes the administration of the scale to a representative sample of repeat mortgage purchasers of a UK bank from 75 completed questionnaires. Using exploratory factor analysis, the scale is purified to 19 items that represent four service experience dimensions.

In Stage 3 we conduct confirmatory factor analysis (CFA) to validate the purified scale based on 218 collected questionnaires from a representative sample, which confirms the scale's reliability and validity. 
Stage 4 introduces the final scale and the conceptual framework of service experience.

INSERT FIGURE 2 HERE

\section{Stage 1: The Qualitative Study}

To articulate the meaning and the domain of service experience, and its measure, the initial stage of our research explores the perceptual attributes of service experience through in-depth interviews using the soft laddering technique (Botschen et al., 1999; Grunert and Grunert, 1995). Soft laddering is a technique using personal in-depth interviews where respondents are restricted as little as possible in their natural flow of speech and is an accepted method for assessing consumers' cognitive structures and underlying purchasing motivations (Reynolds et al., 1995).

Researchers suggests that the context should include only one type of purchase, because the validity of repurchase intentions varies significantly across contexts (Chandon et al., 2005) and a single service is more likely to produce significant results than a study across many services (Darby and Karni, 1973; Sharma and Patterson, 2000). We choose mortgages in the UK because it is an important, complex and considered choice with a long purchase process containing numerous service episodes. Considered purchases are likely to display service experience as a key determinant of customer retention (Sharma and Patterson, 1999). Financial planning services are complex (Sharma and Patterson, 2000), customized and high in credence properties: such properties influence the choice of services (Sharma and Patterson, 2000). Furthermore, as suggested by Lemke et al. (2010), the service experience, and its corresponding measure, are of context-specific nature and therefore need to be explored in one specific setting.

Generating an initial item pool through qualitative research shall be, according to Churchill (1979, p. 67), accomplished with an experience survey conducted with 'a judgment sample of persons who can offer some ideas and insights into the phenomenon'. The objective is to create an initial pool of items, which are then scrutinized thoroughly through other tests. 
We achieved data saturation (Glaser and Strauss, 1967) after conducting individual in-depth interviews with 30 mortgage customers from the UK over a four week period: each interview lasted between 30 to 60 minutes. The sample consisted of customers who had purchased one or more mortgages in the previous six months with one major UK Bank. The split between first time buyers and repeat buyers was 15 each. Customers were recruited by a market research company and offered a $£ 50$ (\$80) incentive for their participation. The sample was randomly selected from amongst the mortgage customers of that bank.

\section{Dimensions of Customer Experience Scale and Item Generation}

The interviews were transcribed and coded with the support of NVivo 8.0. The software enables the authors to reflect on the key themes and code and compare the data (Di Gregorio, 2000; Clisbee, 2003). Coding follows the grounded approach described by Ryan and Bernard (2003), which draws heavily from Strauss and Corbin (1990). We incorporated a systematic and far-out comparison approach and hierarchical coding to ensure that we observed all the data thoroughly and explored all its dimensions (Strauss and Corbin, 1990, pp. 75-95). Based on these interviews, 58 customer experience items were generated.

Three marketing academics, two $\mathrm{PhD}$ students unfamiliar with the details of the research project and five managers of financial services companies assessed the readability of the items. To maximize the content and face validity of the items generated from the exploratory research, a panel of expert judges reviewed the retained item pool (Dagger et al., 2007). The expert panel comprised seven marketing academics familiar with the scale development process. The expert panel members performed three tasks.

First, the expert panel commented on the clarity, conciseness and labeling of the items and defined their own labels for the items. Panel members were asked about the similarity of items, the clarity of phrasing and the terminology used in the scale. This resulted in fifteen items removed or merged with other items. For example, the items Interaction History, 
Experience History and Past Experience Influence were merged into one item labeled Past Experience.

The panel members then rated each item with respect to its relevance to the item description. Ratings were given on a seven-point scale, anchored by $1=$ not at all representative and $7=$ strongly representative. Item purification began with the exclusion of any item rated by the panel members as either a 1 or a 2 on the rating scale. Six members of the panel had to rate the item as a 6 or 7 on the rating scale for an item to be included in the final scale.

Thirdly, the panel members were asked what dimensions and sub-dimensions evolved from the research model and items. Using the Q-sort technique (Funder et al., 2000), each item in the initial pool was printed on an index card and each panel member was asked to create dimensions and sub-dimensions based on the similarity representing aspect of the service experience. It was up to the members to decide on the number of categories he or she used and to find appropriate labels and descriptions of the categories. The proportion of agreement among the judges was high, demonstrating high reliability. The Spearman correlation coefficient between judges is $r=0.84: \mathrm{p}<0.05$.

The sorting procedure (Moore and Benbasat, 1999) generated eight categories of service experience with 37 items. Six items were dropped because a number of judges identified them as being too ambiguous to fit into the emerging categories.

Finally, three marketing academics familiar with the research were given the conceptual description of the eight dimensions and asked to rate the 37 items as either "very applicable," "somewhat applicable," or "not applicable" relative to the respective dimension. Items needed to be rated at least as "somewhat applicable" to be retained. This procedure resulted in retaining all 37 items and five dimensions, the single-item dimension Inertia merged into the Risk dimension, the single item Past Experience dimension merged into Process Experience, and the dimension multi-channel experience, including the items account 
management and multi-channel experience was moved into the dimension Process Experience.

The five dimensions representing 37 items (see Figure 3) are (a) process experience, constituting experiences connected with securing the mortgages, such as process ease (frustration); (b) product experience, representing experiences associated with the features and range of products offered, such as the product diversity and/or additional offerings of the service provider; (c) lifetime costs, signifying the total cost of searching, applying and securing a mortgage, including judgments about the importance of securing the best mortgage

rate available; (d) risk, meaning the perceived risk of accepting a significant financial obligation, and (e) provider experience, highlighting the customer's assessment of all interactions with the service provider before, during and after securing a mortgage: for example, the influence the interpersonal skills of the service provider's personnel had on the customer's decision.

INSERT FIGURE 3 HERE

The findings indicate that service experience is a holistic construct (Verhoef et al., 2009), including determinants such as social interactions (Bagozzi, 2000), price (Baker et al., 2002), brand (Brodie et al., 2006) and channels. The validity of the findings is scrutinized in the subsequent quantitative data analysis as outlined in Figure 1.

\section{Stage 2: Scale Purification through Exploratory Factor Analysis (EFA)}

The scale was purified through a subsequent phase of quantitative research conducted amongst repeat purchasers: EFA. Data were collected through an online questionnaire accessible through a link sent by the bank to a sample of customers who had purchased more than one mortgage from the bank and the most recent mortgage within the previous six months, resulting in a sample of repeat purchasers. The data test the appropriateness of the 
37 items for generating the above five dimensions of service experience, hence refining the scale. The corresponding survey generated 75 qualified responses, which were subsequently analyzed utilizing the software packages SPSS 16.0 and AMOS 16.0.

Prior to conducting the exploratory factor analysis, four tests were consulted to assess the suitability of the data for factor analysis. The Bartlett Test of Sphericity tested the overall significance of the correlation matrix and the Kaiser-Meyer-Olkin (KMO) measure of sampling adequacy to establish the suitability of the data for factor analysis (Tabachnick and Fidell, 2001; Hair et al., 1998). The correlation matrix was examined to ensure that inter-item correlations were substantial $(>0.30)$ and the anti-image matrix was assessed for low values (Hair et al., 1998). The Catell screen plot was also used as a diagnostic indicator for factor extraction. As the factors are expected to be correlated, we obliquely rotated the factors using the direct oblim procedure (Hair et al., 1998; Polit, 1996). The results of the factor analysis were assessed in conjunction with the results from scale reliability analysis using Cronbach's alpha and item-to-total correlations. In the analysis process, 18 items were eliminated due to high cross-loadings, insufficient values on the anti-image matrix and their item-to-total correlation. Our approach of sequentially eliminating items with low loadings on all factors, or high cross-loading on two or more factors, followed by factor analysis of the remaining items has been used in widely cited analogous scale development studies (Parasuraman et al., 2005). The number of items dropped after the purification stage are not necessary an indicator that a unique part of the latent variable is missing. For example, for the E-S-QUAL scale, a scale development process and construct similar to service experience, the items were purified from a set of 121 items to 22 items (Parasuraman et al., 2005). This is supported by our analysis, namely: The remaining data pass the threshold for sampling adequacy: KMO MSA .779 passes Bartlett's test of sphericity significance with .000 , displays a substantial inter-item correlation with the highest being .251 and generates acceptable values on the antiimage matrix. The screen plot suggests a factoring of 19 items in four dimensions explaining 88.4 per cent of all variances. A Cronbach Alpha factor of .724 and the fact that each of the remaining items of the scale EXQ displays an item-total correlation of at least .735, support the validity and reliability of the scale. 
The purpose of the exploratory factor analysis is to summarize the data into a minimum number of factors for prediction purposes. The resulting purified scale (see Figure 4) developed posits service experience as comprising four primary dimensions with 19 corresponding items developed to operationalize each of these dimensions. The resulting four dimensions and corresponding items were presented to five marketing academics familiar with the research. The expert panel was given the conceptual description of the four dimensions and asked to rate the four dimensions description as either "very applicable," "somewhat applicable," or "not applicable" relative to the dimension and its items. Dimension descriptions needed to be rated at least as "somewhat applicable" to be retained. This procedure resulted in the labeling of the following dimensions of service experience.

\section{Findings Purification Stage}

After purification, 19 items in four dimensions remained, namely:

1. Product experience - The emphasis of this dimension is the importance of customers' perception of having choices and the ability to compare offerings. Choice dynamics are established as a critical factor in modeling consumer behavior (McAlister and Srivastava, 1991) and as an antecedent of loyalty (Srinivasan et al., 1998). Interviewees often referred to the need to compare offerings, even if they were from the same provider differing only in terms of lengths of the mortgage, because it "gave them the feeling of having a choice", and without a choice they were unlikely to accept the offer "no matter how good it was". It also comprises attributes assigned to the product experience dimension from the qualitative research, such as the wish for 'one designated contact' to deal with throughout the entire mortgage process, which is suggested to be a critical ingredient in the evaluation of service quality perceptions (Johnston, 1997).

2. Outcome focus - is associated with reducing customers' transaction cost, such as seeking out and qualifying new providers. This dimension reflects the importance of goal-oriented experiences in consumer behavior (Huffman and Houston, 1993), suggested by statements 
such as: "We just wanted to get the mortgage as soon as possible." Also, once the relationship is established, these goal-oriented past experiences (Roy et al., 1996) are seen as a strong basis on which to build a habit despite the awareness of other offerings and the competitiveness of the existing provider, as indicated by the comment "I know there are better offers, but why should I bother; here I know what I will get and it's straightforward."

3. Moments-of-truth - This dimension is characterized by what has been suggested by the literature as moments-of-truth, emphasizing the importance of service recovery (Tax et al., 1998) and flexibility (Liljander and Strandvik, 1993), dealing with customers once complications arise in the process of acquiring a mortgage. The dimension explains the influence of service providers' behavior on the current and future decision of the customer in case of a mishap (De Yong and De Ruyter, 2004). Furthermore, the dimension incorporates evaluations of the interpersonal skills connected to the moments-of-truth and their influence on customers' perception of risk in dealing with the service provider (Crosby et al., 1990). An example of a corresponding statement is: "I was really upset about what happened, but the way they (the service provider) dealt with me gave me the confidence that I had made the right decision in staying with them."

4. Peace-of-mind - This dimension describes the customer's assessment of all the interactions with the service provider before, during and after securing a mortgage. This dimension includes statements strongly associated with the emotional aspects of service (Liljander and Strandvik, 1997; Edvardsson, 2005) and takes many items from the qualitatively generated dimension of provider experience. The dimension is reflecting the emotional benefits customers experience based on the perceived expertise of the service provider (Bendapudi and Berry, 1997) and guidance throughout the process, which appeared to the customers not only as easy (Dabholkar et al., 1996), but also seemed to be, as comments suggest, "putting them at ease" and, subsequently, "increasing their confidence in the provider," (Bendapudi and Berry, 1997). Customers react to the peace-of-mind often with a notion of looking at building "a relationship" with a service provider rather than looking at the mortgage in a "purely transactional way," (Geyskens et al., 1996). 
Interestingly, most of the items in the qualitatively generated dimension of lifetime costs proved to be statistically irrelevant. This indicates that what is described as the total costs of searching, applying, securing and paying for the mortgage is not significantly related to the quality of service experience. The costs associated with searching for a mortgage, however, are now captured by the dimension outcome focus. The outcomes of the service encounter, described by the literature as the technical quality of the service, are reflected in the attributes PEA4 convenience retention and OUT1 inertia.

\section{Stage 3: Reliability and Validity Assessment of Measure}

Next, we conducted confirmatory factor analysis to assess further the factor structure of the EXQ scale. To perform the analysis we collected an additional sample. Data were collected through an online questionnaire accessible through a link sent by the bank to a sample of repeat customers who purchased their most recent mortgage within the previous six months. The corresponding online link was available for two weeks after the invitations to participate were sent, and 218 qualified responses were collected. Respondents rated their customer experience on each scale item using a 7 -point scale $(1=$ Strongly disagree, $7=$ Strongly agree) with a "Do not know/Not applicable" option alternative next to each item. The items are grouped by dimensions for expositional convenience; they appeared in random order on the survey. The symbols preceding the items correspond to the variables named in Figure 4 (see Appendix A).

Prior to data analysis a preliminary preparation of the data was conducted as outlined in Stage 2. In order to verify the factor structure and dimensionality of the refined scale, researchers need to collect a sufficient number of responses. According to Hair et al. (1998), the sample size needed to conduct confirmatory factor analysis is five observations per scale item. Thus, the sample size for the validation stage of the study of 218 qualified responses exceeds the requirements to achieve a high level of statistical power. 
Table 1 contains descriptive profiles of the exploratory and confirmatory stage. The samples are analogous and a $\chi^{2}$ exposed that the samples do not differ significantly in terms of age, gender and educational background. However, household income and occupational data were not available.

\section{INSERT TABLE 1 HERE}

In order to investigate and confirm that all items of the EXQ dimensions truly represent the corresponding latent construct, we incorporate a partial disaggregation approach (Bagozzi and Heatherton, 1994; Dabholkar, Thorpe and Rentz, 1996; Sweeney, Soutar and Johnson, 1999); this approach is widely used in scale development studies (Dagger et al., 2007). The partial disaggregation approach is a compromise between an aggregate approach, in which all items are summed to form a single composite indicator of a construct, and a disaggregate approach, in which each item is treated as an individual indicator of the relevant factor (Bagozzi and Heatherton, 1994; Bagozzi and Foxall, 1996; Sweeney, Soutar and Johnson, 1999). Partial disaggregation overcomes the difficulties inherent in a disaggregate model by reducing random error and producing more stable estimates while maintaining the multiple indicator approach to structural equation modeling (Bagozzi and Heatherton, 1994; Dabholkar, Thorpe and Rentz, 1996; Sweeney, Soutar and Johnson, 1999; Garvner and Mentzner, 1999). The composite items applied to the partial disaggregation approach adopted in our research were operationalized according to the guidelines set forth in the literature (Bagozzi and Heatherton, 1994; Dabholkar, Thorpe and Rentz, 1996; Garvner and Mentzner, 1999; Sweeney, Soutar and Johnson, 1999). On this basis, items reflecting a particular construct were grouped at random to form a composite indicator. The assignment of items to composites is arbitrary as all items reflecting a latent construct are assumed to represent that construct in a similar fashion (Sweeney, Soutar and Johnson, 1999).

The fit of the measurement and structural models examined was assessed through multiple indices, as recommended by Hoyle and Panter (1995). Measures of incremental fit were used as indicators of acceptable model fit. In particular, the type-2 incremental fit index (IFI) and type-3 comparative fit index (CFI), and root mean square error of approximation (RMSEA) 
were selected ${ }^{1}$. The recommended threshold of $>0.90$ was adopted as indicative of adequate model fit for these indices (i.e. IFI, CFI). The accepted level for the root mean-square error of approximation (RMSEA) measure was $<0.10$, with lower values indicating better model fit (Hair et al. 1998, p.772). Thus, EXQ's RMSEA score of .05 demonstrates an excellent model fit. The scale statistics (see Table 2) indicate the robustness of the EXQ model (Hoyle and Panter, 1995; Garvner and Mentzner, 1999) on the basis of the fit criteria established in prior service quality research (Parasuraman et al., 2005).

INSERT TABLE 2 HERE

The psychometric properties of the scale were evaluated through a comprehensive CFA. All items were tested in the same model and were restricted to load on their respective factors. The results are a sign of high levels of construct reliability and average variance extracted for all latent variables. All $t$ values were significant and the average variances extracted were greater than 0.50 , thus convergent validity was established. Using Fornell's and Larcker's $(1981)^{2}$ stringent criteria for measuring the internal consistency of a scale and its ability to measure a latent construct, we establish construct reliability with estimates exceeding 0.50 (see Table 3 ). In the case of an exception, we successfully applied the $\chi^{2}$ test for discriminant validity (Anderson and Gerbing, 1988).

\section{INSERT TABLE 3 HERE}

After establishing the strength and psychometric properties of the scales underpinning the model, we examined the structure of the model. We modeled service experience as suggested

\footnotetext{
${ }^{1}$ Type-2 incremental fit index (IFI) and type-3 comparative fit index (CFI) were selected based on their robustness to sample size variations (Hoyle and Panter, 1995).

2 Scale reliability was assessed using Fornell and Larcker's (1981) construct reliability formula: $\mathrm{CREL}=(\Sigma \lambda) 2 /[(\Sigma \lambda) 2+\Sigma(1-\lambda \mathrm{j} 2)]$. This formula measures the internal consistency of a scale and its ability to measure a latent construct. According to this approach, construct reliability estimates exceeding 0.50 are indicative of acceptable scale reliability (Fornell and Larcker, 1981).
} 
by researchers as a formative ${ }^{3}$ construct in which the dimensions of the model drive service experience perceptions (Parasuraman et al., 2005). It is noteworthy that these scale items are specified as reflective based on the decision criteria of Jarvis et al., (2003). At the dimensional level, Jarvis, MacKenzie, and Podsakoff (2003) suggested that the formative approach is appropriate (a) when the direction of causality is from the dimensions to the construct, the dimensions serve as defining characteristics of the construct, and changes in the dimensions should cause changes in the construct and (b) when the dimensions do not have the same or similar content, do not necessarily covary with one another, and do not have the same antecedents or consequences. On the basis of these criteria, we treated the dimensions as formative indicators of the higher order service experience construct. At the measurement level (item level) Jarvis, MacKenzie, and Podsakoff suggested that the reflective approach is appropriate when (a) the relative homogeneity and interchangeability of scale items is high, (b) the degree of covariation among items within each dimensions is high, and (c) indicators within each dimension are likely to be affected by the same antecedents and have similar consequences. The relative homogeneity, and hence interchangeability of scale items within each dimension, the high degree of covariation among items within each dimension and the expectation that indicators within each dimension (e.g. interpersonal skills) are likely to be affected by the same antecedents (e.g. branch) and have similar consequences. In addition, we conducted second-order CFAs in which the dimensions of EXQ (e.g. product experience) were modeled as reflective indicators of a second-order overall service experience (EXQ) construct. The CFA analysis and model fit statistics were analogous to those reported in this study. On the basis of these criteria, we modeled the measurement aspect of our model reflectively (see Figure 5). Therefore, the confirmatory factor analysis (CFA) results reported are for first-order factor models specifying the scale items as reflective indicators of their corresponding latent constructs and allows the latent constructs to intercorrelate.

\footnotetext{
${ }^{3}$ However, not all latent constructs are entities that are measurable with a battery of positively correlated items (Edwards and Bagozzi 2000). A less common, but equally plausible approach is to combine a number of indicators to form a construct without any assumptions as to the patterns of intercorrelation between these items. A formative or causal index (Blalock, 1964) results where causality flows in the opposite direction, from the indicator to the construct. Although the reflective view dominates the psychological and management sciences, the formative view is common in economics and sociology. The distinction between formative and reflective measures is important because proper specification of a measurement model is necessary to assign meaningful relationships in the structural model (Anderson and Gerbing, 1988). Theoretical work in construct validity (Blalock, 1982) and structural equation modeling (Baumgartner and Homburg, 1996) enhances our understanding, yet considerable debate still exists regarding the procedures a working researcher should follow to achieve construct validity (Diamantopoulos, 2005).
} 


\title{
Stage 4: Conceptual Framework, Additional Assessment (SEM) and Connection to
}

\section{Outcomes}

Considering the above findings, our conceptualization of service experience and the resulting reliable and valid scale, we offer the following definition of service experience (see Figure $5)$ :

\author{
Service experience is the customer's assessment of all attributes of their \\ direct and indirect dealings with a service provider that explains their \\ behavioral loyalty through repeat purchasing. Its dimensions are product \\ experience, outcome focus, moments-of-truth and peace-of-mind (POMP).
}

\section{DISCUSSION}

\section{The Construct of Service Experience}

Our study develops a four dimensional conceptualization of service experience and the corresponding items for each dimension by means of a scale development process. The resulting scale EXQ is assessed through validity and reliability analysis of two scale data collections, assuring the sufficient conceptualization of customer experience through the scale. The nomological validity of the scale is established by linking the scale dimensions and the overall scale to the repurchasing behaviour of the sample.

The findings suggest that customers base their perceptions of service experience on four dimensions: product experience, outcome focus, moments-of-truth and peace-of-mind (POMP). The findings indicate that customers evaluate the service experience at an overall level, a dimensional level and at attribute level and that each level drives perception on the level above. 
The findings improve our understanding of how customers evaluate their service experience by linking their evaluation to important marketing outcomes, namely purchasing and repurchasing behavior.

EXQ, and its empirically derived construct of service experience, offer a stimulus and foundation to advance service marketing, particularly service quality and service experience research, by delivering a measure capable of capturing all facets of the construct of the service experience (Verhoef et al., 2009). Moreover, this scale measures the impact of the distinctive drivers of the service experience on each of the components of the service experience (Verhoef et al., 2009).

The findings support previous conceptual papers that suggest the service experience is broadly based (Shembri, 2006; Berry et al., 2006), yet not as broad as suggested by some (Verhoef et al., 2009; Gentile et al., 2007; Meyer and Schwager, 2007). The posited dimensions of social interactions (Bagozzi, 2000), brand image (Brodie, 2009) and price (Baker et al., 2002) are not supported in this study, which could be attributed to the fact that our sample constitutes repurchasing customers. However, just because these customers repurchased, doesn't mean that they only had service experiences with one provider. The implication of our findings is that scholars risk overcompensating for service quality's limitations by defining service experience too widely.

Our qualitative research supports the holistic and total nature of the service experience constructs as posited in the literature. In the quantitative stages, some of these dimensions could not be confirmed as part of the construct. In particular, the findings could not support the following three of the eight dimensions of the Verhoef et al. (2009) model: social environment, retail atmosphere and retail brand. The relevance of the dimensions lifestyle and sensorial from the Gentile et al. (2007) model could also not be supported. One could speculate that the context of this research differs significantly from the retail context, the foundation of both Gentile et al.'s (2007) and Verhoef et al.'s (2009) research. We compare our results with extant conceptualizations in Table 4 below. 
INSERT TABLE 4 HERE

The assessment of the overall service experience, as measured by the scale EXQ, reflects the evaluation of customers who recently repurchased a mortgage with a financial service provider. The strong association between service experience quality and repurchasing behavior is noteworthy because satisfaction is generally viewed as more closely aligned with behavior (Cronin and Taylor, 1992). The findings support the high impact of the overall service experience and its dimensions on the important marketing outcome of repurchasing behavior.

\section{Managerial Implications}

The recent management interest in service experience is validated by the findings, which link service experience to important marketing outcomes.

EXQ provides a measure to help managers benchmark and track performance over time. More importantly, it illustrates a detailed structure whereby managers can determine which attributes of the customers' service experience are most strongly associated with the marketing outcomes organizations are trying to achieve. This is a positive contribution to making marketing more accountable as managers can relate investments in service experience more directly with the outcomes closest to income such repurchasing behavior.

Managers should consider service experience as an important strategic objective. Based on the attributes and dimensions of service experience, we believe that our findings are of particular relevance to other high involvement, high contact professional services. 
The findings confirm that there are aspects of the service experience that are beyond the direct control of managers; for example, customers' past experiences with other service providers alter the service experience evaluations of potential customers. The same is true for advice given by other customers or peer groups of potential customers. Managing the service experience is, therefore, different from managing customer service which focuses upon single service episodes under the control of the organization (Klaus, 2011).

By delivering evidence that service experience is a valid new construct of customers' service evaluations, our research challenges the dominant service quality causal chain in explaining consumer behavior (Klaus and Maklan, 2007). This notion posits service quality as a key determinant of customer satisfaction, customer satisfaction as an antecedent of repurchasing behavior and subsequent financial performance.

\section{Limitations and directions for future research}

As with any study, this research has several limitations. Our study focuses upon a particular service setting and in one country, with a sample of repurchasing customers. Whilst it seems reasonable to suggest that these findings will extend to similar service settings, this needs to be researched. The relationship between the mortgage provider and its customers exists in a highly contractual, regulated and utilitarian service setting. Other researchers may wish to investigate more hedonic consumption services and other non-contractual services. This study cannot assess cultural differences in consumers' assessment of service experience. Cross-industry, cross-sectional and cross-national data would provide more confidence in the dimensions we present and ultimately could be used to build industry-specific benchmarking tools.

It would also be interesting to see how the EXQ dimensions are relevant for non-customers. We do not believe that the goal of service marketing research is to focus firms exclusively on 
serving their existing customers; it seems intuitively obvious that all firms need a balance of customer acquisition and development.

Repeating the study with longitudinal data would strengthen claims for EXQ with respect to observed consumer behavior. The scale used for loyalty in this study reflects stated behavior and affective commitment.

It will be desirable to assess EXQ scale's discriminate validity versus related scales such as SERVQUAL. Lastly, prior research suggests that service experience affects business performance and future research should determine if EXQ and its dimensions explain important marketing outcomes such as market share, share of wallet and ultimately profitability.

\section{CONCLUSIONS}

The service experience scale EXQ developed in this study can be used to monitor and improve the quality of experiences delivered to customers. Although developed in the context of mortgages, this instrument may be of interest to other providers of high-involvement, highimpact services. The findings of the study provide managers with valuable insight into the dimensions that reflect customers' service experience perceptions. This knowledge can subsequently be used to improve and manage the customers' service experience and its quality. The authors hope that the scale will stimulate and facilitate additional research on EXQ and also assist managers in systematically assessing and improving EXQ. 


\section{REFERENCES}

Abbott, L. (1955), Quality and Competition. New York: Columbia University Press.

Ajzen, I. and Fishbein, M. (1977), "Attitude-behavior relations: a theoretical analysis and review of empirical research," Psychological Bulletin, 84 (5), 888-918.

Anderson, E., Fornell, C. and Lehmann, D. (1994), "Customer satisfaction, market share, and profitability: findings from Sweden”, Journal of Marketing, 58 (3), 53.

Anderson, J. and Gerbing, D. (1988) "Structural equation modeling in practice: a review and recommended two-step approach," Psychological Bulletin, 103 (3), 411-23.

Arnould, E. and Price, L. (1993), "River magic: Extraordinary experience and the extended service encounter," Journal of Consumer Research, 20 (1), 24-45.

Badget, M., M. Moyce and Kleinberger, H. (2007), Turning Shopper into Advocates. IBM Institute for Business Value.

Bagozzi, R. and Heatherton, T. (1994), "A general approach to representing multifaceted personality constructs: Application to state self-esteem," Structural Equation Modeling, 1 (1), $35-67$.

Bagozzi, R.and Foxall G.(1996), "Construct validation of a measure of adaptive-innovative cognitive styles in consumption," International Journal of Research in Marketing, 13 (3), 201-13.

Bagozzi, R. (2000), "On the concept of intentional social action in consumer behavior," Journal of Consumer Research, 27 (3), 388-96.

Baker, J., A. Parasuraman, D. Grewal and Voss, G. (2002), "The influence of multiple store environment cues on perceived merchandise value and patronage intentions," Journal of Marketing, 66 (2), 120-41.

Bendapudi, N. and Berry, L. (1997), “Customers' motivations for maintaining relationships with service providers," Journal of Retailing, (73), 15-37.

Bendapudi, N. and Leone, R. (2003), "Psychological implications of customer participation on co-production," Journal of Marketing, 67 (January), 14-28.

Berry, L., L. Carbone and Haeckel, S. (2002), "Managing the total customer experience," MIT Sloan Management Review, 43 (3), 85.

Berry, L., E. Wall and Carbone, L. (2006), "Service clues and customer sssessment of the service experience: Lessons from marketing," Academy of Management Perspectives, 20 (2), 43-57.

Bitner, M., W. Faranda, A. Hubbert and Zeithaml, V. (1997), "Customer contribution and roles in service delivery," International Journal of Service Industry Management, 8 (3), 193205.

Botschen, G., E. Thelen and Pieters, R. (1999), "Using means-end structures for benefit segmentation: an application to services," European Journal of Marketing, 33 (1), 38-58. 
Brady, M. and Cronin, J. (2001), "Some new thoughts on conceptualizing perceived service quality: a hierarchical approach," Journal of Marketing, 65 (3), 34-49.

Brakus, J., Schmitt, B. and Zarantonello, L. (2009), "Brand experience: What is it? How is it measured? Does it affect loyalty?” Journal of Marketing, 73 (3), 52-68.

Brodie, R., Glynn, M. and Little, V. (2006), "The service brand and the service-dominant logic: Missing fundamental premise or the need for stronger theory?" Marketing Theory, 6 (3), 363.

Brodie, R. (2009), "From goods to service branding: an integrative perspective," Marketing Theory, 9 (1), 107-11.

Buttle, F. (1996), "SERVQUAL: review, critique, research agenda", European Journal of Marketing, 30 (1), 8-32.

Buzzell R. and Gale B., (1987), The PIMS Principles: Linking Strategy to Performance, Free Press, NY.

Chandon, P., Morwitz, V. and Reinartz, W. (2005), "Do intentions really predict behavior? Self-generated validity effects in survey research," Journal of Marketing, 69 (2), 1.

Churchill, G. (1979), "A paradigm for developing better measures of marketing constructs," Journal of Marketing Research, 16 (1), 64-73.

Clisbee, M. (2003), "Using N-Vivo for literature analysis: Strategies in Qualitative Research: Methodological Issues and Practices Using QSR NVivo and NUD*IST", London: University of London.

Cova, B. and Pace, S. (2006), "Brand community of convenience products: New forms of customer empowerment - the case "my Nutella - the community'," European Journal of Marketing, 40 (9/10), 1087-105.

Cowley, E. (2008), Looking back at an experience through rose-colored glasses. Journal of Business Research, 61, 1046-1052.

Crosby, L., Evans, K. and Cowles, D. (1990), "Relationship quality in services selling: An interpersonal influence perspective," Journal of Marketing Research, (54), 68-81.

Cronin, J. and Taylor, S. (1992), "Measuring service quality: a re-examination and extension," Journal of Marketing, 56 (3), 55-68.

Dabholkar, P., Thorpe, D. and Rentz, J. (1996). "A measure of service quality for retail stores: Scale development and validation," Journal of the Academy of Marketing Science, 24 (1), 3-16.

Dagger, T., Sweeney, J. and Johnson, L. (2007), "A hierarchical model of health service quality: Scale development and investigation of an integrated model," Journal of Service Research, 10 (2), 123-42.

Danermark, B., Ekstrom, M., Jakobsen, L. and Karlsson, J. (2002), Explaining Society: Critical Realism in the Social Sciences. London: Routledge. 
Darby, M. and Karni, E. (1973), "Free competition and the optimal amount of fraud," Journal of Law and Economics, 16 (1), 67-88.

Day, R. (1980), "Research perspectives on consumer complaining behavior", in Theoretical Developments in Marketing, C. W. Lamb and P. M. Dunne, eds. Chicago, IL: American Marketing Association, 211-15.

De Jong, A. and De Ruyter, K. (2004), "Adaptive versus proactive behavior in service recovery: the role of selfmanaging teams," Decision Sciences, (35), 457-491.

Diamantopoulos, A. and Winklhofer, H. (2001), "Index construction with formative indicators: an alternative to scale development," Journal of Marketing Research, 38 (2), 26977.

Diamantopoulos, A. (2005), "The C-OAR-SE procedure for scale development in marketing: a comment," International Journal of Research in Marketing, 22 (1), 1-9.

Di Gregorio, S. (2000), "Using Nvivo for your Literature Review". Paper presented at the Meeting of the Strategies in Qualitative Research: 1 Issues and Results from the Analysis using QSR NVivo and NUD*IST", London. Retrieved January 2nd, 2010, from http://www.sdgassociates.com/downloads/literature_review.pdf.

Edvardsson, B., Friman, M. and Roos, I. (2007), "Service quality grounded in customer experiences, affect and relationships" in Service Excellence als Impulsgeber, eds. Gouthier M., Coenen, C. Schulze, H. And Wegmann, C., Gabler, Germany.

Edvardsson, B., Gustafsson, A. and Roos, I. (2005), "Service portraits in service research - a critical review”, International Journal of Service Industry Management, 16 (1), 107-121.

Edvardsson, B. (2005), "Service quality: Beyond cognitive assessment," Managing Service Quality, 15 (2), 127-31.

File, K. and Prince, R. (1992), "Positive word-of-mouth: Customer satisfaction and buyer behavior," International Journal of Bank Marketing, 10 (1), 25-9.

Flint, D. and Mentzer, J. (2006), "Striving for integrated value-chain management given a service-dominant logic for marketing," in The Service-Dominant Logic of Marketing, R. Lusch and S. Vargo, eds. Armonk, NY: M.E. Sharpe, 139-49.

Fornell, C., Mithas, S., Morgeson, F. and Krishnan, M. (2006), "Customer satisfaction and stock prices: high returns, low risk”, Journal of Marketing, 70 (1), 3-14.

Fornell, C. and Larcker, D. (1981), "Evaluating structural equation models with unobservable variables and measurement error," Journal of Marketing Research, 18 (1), 39-50.

Frow, P. and Payne, A. (2007), "Towards the 'perfect' customer experience," Journal of Brand Management, 15 (2), 89-101.

Funder, D., Furr, R. and Colvin, C. (2000), "The riverside behavioral Q-sort: a tool for the description of social behavior," Journal of Personality, 68 (3), 451-89.

Garver, M. and Mentzer, J. (1999), "Logistics research methods: Employing structural equation modeling to test for construct validity," Journal of Business Logistics, 20 (1), 33-57. 
Gentile, C., Spiller, N. and Noci, C. (2007), "How to Sustain the Customer Experience: an Overview of Experience Components that Co-create Value with the Customer," European Management Journal, 25 (5), 395-10.

Geyskens, I., E. Jan-Benedict, M. Steenkamp, L. Scheer, and N. Kumar (1996), "The effects of trust and interdependence on relationship commitment: A trans-atlantic study," International Journal of Research in Marketing 13 (4), 303-317.

Gilmore, J., and Pine, B. (2002), Customer experience places: The new offering frontier. Strategy \& Leadership, 30, 4-11.

Glaser, B. and Strauss, A. (1967), The Discovery of Grounded Theory: Strategies for Qualitative Research. Chicago: Aldine Publishing Company.

Grewal, D., Levy, M., and Kumar, V. (2009), Customer experience management in retailing: An organizing framework. Journal of Retailing, 85, 1-14.

Gronroos, C. (1997), "Value-driven relational marketing: From products to resources and competencies," Journal of Marketing Management, 13 (5), 407-419.

Grunert, K. and Grunert, S. (1995), "Measuring subjective meaning structures by the laddering method: theoretical considerations and methodological problems", International Journal of Research in Marketing, 12 (3), 209-25.

Haeckel, S., Carbone, L. and Berry, L. (2003), "How to lead the customer experience," Marketing Management, 12 (1), 18.

Hair, J., Anderson, R., Tatham, R. and Black, W. (1998), Multivariate Data Analysis. Upper Saddle River, NJ: Prentice Hall International.

Havlena, W., and Holbrokk, M. (1986), The varieties of consumption experience: Comparing two typologies of emotion in consumer behavior. Journal of Consumer Research, 13, 394404.

Hirschman, E. and Holbrook, M. (1982), "Hedonic consumption: Emerging concepts, methods and propositions," Journal of Marketing, 46 (3), 92-101.

Holbrook, M. (2006), "Book reviews - the consumption experience," Journal of Macromarketing, 26 (2), 259-66.

Howard, J. and Sheth. J. (1969), The Theory of Buyer Behavior. New York: John Wiley.

Hoyle, R. and Panter, A. (1995), "Writing about structural equation models," in Structural Equation Modelling, R. Hoyle, ed. Thousand Oaks, CA: Sage Publications, 158-176.

Huffman, C. and Houston, M. (1993), "Goal-oriented experiences and the development of knowledge," Journal of Consumer Research, 20 (2), 190-207.

Izard, E. (1977), Human Emotions. New York: Plenum Press.

Jarvis, C., MacKenzie, S. and Podsakoff, P. (2003), "A critical review of construct indicators and measurement model misspecification in marketing and consumer research," Journal of Consumer Research, 30 (2), 199-18. 
Johnston, R. (1997), "Identifying the critical determinants of service quality in retail banking: importance and effect," International Journal of Bank Marketing, 15 (4), 111-16.

Johnston, R. and Clark, G. (2008), Service Operations Management, 3rd ed. London: Financial Times/Prentice Hall.

Keaveney, S. (1995), "Customer switching behavior in service industries: an exploratory study," Journal of Marketing, 59 (2), 71.

Keynes, J. (1936), The General Theory of Employment, Interest and Money. Cambridge: Macmillan Cambridge University Press.

Klaus, Ph. (2011): Quo vadis, customer experience? In: Beyond CRM: Customer Experience in the Digital Era. Strategies, Best Practices and Future Scenarios in Luxury and Fashion, Rusconi, C., ed., Franco Angeli, Milano.

Klaus, Ph. and Maklan, S. (2007), "The role of brands in a service dominated world", Journal of Brand Management, 15 (22), 115-22.

Klaus, Ph. and Maklan, S. (2011), "Bridging the gap for destination extreme sports - a model of sports tourism customer experience," Journal of Marketing Management, 27 (13-14).

Kozinets, R. (2002), "The field behind the screen: Using netnography for marketing research in online communities," Journal of Marketing Research, 39 (1), 61-72.

LaSalle, D. and Britton, T. (2003), Priceless: Turning Ordinary Products into Extraordinary Experiences. Boston: Harvard Business School Press.

Lee, G. and Lin, H. (2005), "Customer perceptions of e-service quality in online shopping", International Journal of Retail \& Distribution Management, 33 (2/3), 161.

Lemke, F., Clark, M., and Wilson, H. (2010), Customer experience quality: an exploration in business and consumer contexts using repertory grid technique. In online advance publication for Journal of Academy of Marketing Science, DOI 10.1007/s11747-010-0219-0.

Liljander, V. and Strandvik, (1997), "Emotions in service satisfaction," International Journal of Service Industry Management, 8 (2), 148.

Liljander, V. and Strandvik, T. (1993), "Estimating zones of tolerance in perceived service quality and perceived service value," International Journal of Service Industry Management, $4(2), 6-28$.

Lusch, R. and Vargo, S. (2006), "Service-dominant logic: reactions, reflections and refinements", Marketing Theory, 6 (3), 281.

Lutz, R.J. (1975), "Changing brand attitudes through modification of cognitive structure," Journal of Consumer Research, 1 (March), 49-59.

Maklan, S. and Klaus, Ph. (2011), "Customer experience: Are we measuring the right things," International Journal of Market Research, 53 (6). 
Mano, H., and Oliver, R. (1993), "Assessing the dimensionality and structure of the consumption experience: Evaluation, feeling, and satisfaction", Journal of Consumer Research, 20, 451-466.

Mascarenhas, O., Kesavan, R. and Bernacchi, M. (2006), "Lasting customer loyalty: a total customer experience approach," Journal of Consumer Marketing, 23 (7), 397.

Maxham, J. and Netemeyer, R. (2002), "A longitudinal study of complaining customers' evaluations of multiple service failures and recovery efforts," Journal of Marketing, 66 (4), $57-72$.

McAlister, L. and Srivastava, R. (1991), "Incorporating choice dynamics in models of consumer behavior," Marketing Letters, 2 (3), 241-52.

Mehrabian, A., and Russell, J. (1974). Approach to environmental psychology. Cambridge, MA: MIT Press.

Meyer, C. and Schwager, A. (2007), "Understanding customer experience," Harvard Business Review, 85 (2), 117-26.

Mooradian, T., and Olver, J. (1997), "I can't get no satisfaction: The impact o f personality and emotion on postpurchase processes." Psychology \& Marketing, 14, 379-393.

Moore, G. and Benbasat, I. (1999), "Development of an instrument to measure the perceptions of adopting an information technology innovation," Information Systems Research, 2 (3), 192-22.

Morrison Coulthard, L. (2004), "Measuring service quality," International Journal of Market Research, 46 (4), 479-497.

Neely, A. (2008), "Exploring the financial consequences of the servitization of manufacturing," Operations Management Research, 1, 103-118.

Oliver, R. (1999), Value as excellence in the consumption experience. In M. Holbrook (Ed.), Consumer value: A framework for analysis and research (pp. 43-62). London, UK: Routledge.

Oliver, R. (1994), "Conceptual Issues in the structural analysis of consumption emotion, satisfaction and quality: Evidence in a service setting", Advances in Consumer Research, 21, $16-22$.

Oliver, R. (1992), "An investigation of the attribute basis of emotion and related affects in consumption: Suggestions for a stage-specific satisfaction framework", Advances in Consumer Research, 19, 237-244.

Olson, J. and Reynolds, T. (1983), "Understanding consumers' cognitive structures: Implications for advertising strategy," in Advertising and Consumer Psychology, L. Percy and A. Woodside, eds. Lexington, MA: Lexington Books.

Parasuraman, A., Zeithaml, V. and Berry, L. (1988), "SERVQUAL: a multiple-item scale for measuring consumer perceptions," Journal of Retailing, 64 (1), 12. 
Parasuraman, A., Zeithaml, V. and Malhotra, A. (2005), "E-S-QUAL: a multiple-item scale for assessing electronic service quality," Journal of Service Research, 7 (3), 213-34.

Parsons, T. (1934), "Some reflections on the nature and significance of economics," Quarterly Journal of Economics, 48 (3), 511-45.

Payne, A., Storbacka, K., and Frow, P. (2008), Managing the co-creation of value. Journal of the Academy of Marketing Science, 36, 83-96.

Phillips, L., Chang, D. and Buzzell, R. (1983), "Product quality, cost position and business performance: a test of some key hypotheses", Journal of Marketing, 47 (2), 26-43.

Pine, B. and Gilmore, J. (1998), "Welcome to the experience economy," Harvard Business Review, 76 (4), 97-105.

Pine, B. and Gilmore, J. (1999), The Experience Economy: Work is Theatre and Every Business a Stage. Cambridge, MA: Harvard Business School Press.

Polit, D. (1996), "Factor analysis," in Data Analysis and Statistics for Nursing Research. Stamford, CT: Appleton and Lange, 345-79.

Pullman, M. and Gross, M. (2004), "Ability of experience design elements to elicit emotions and loyalty behaviors," Decision Sciences, 35 (3), 551.

Prahalad, C. and Ramaswamy, V. (2004), "Co-creation experiences: the next practice in value creation," Journal of Interactive Marketing, 18 (3), 5.

Reibstein, D., Day, G. and Wind, J. (2009), “Is marketing academia losing its way?" Journal of Marketing, 73 (4), 1-3.

Reichheld, F. (2003), "The one number you need to grow," Harvard Business Review, 81 (12), 46-54.

Reinartz, W., and Ulaga, W. (2008), How to sell services more profitably. Harvard Business Review, 86, 90-96.

Reynolds, T. and Gutman, J. (1988), "Laddering theory, method, analysis, and interpretation," Journal of Advertising Research, 28 (1), 11-31.

Reynolds, T., Gengler, C. and Howard, D. (1995), "The Means-end analysis of brand persuasion through advertising," International Journal of Research in Marketing, 12 (3), 25766.

Roy, R., Chintagunta, P. and Haldar, S. (1996), "A framework for investigating habits, the hand of the past and heterogeneity in dynamic brand choice," Marketing Science, 15 (3), 280-99.

Ryan, G. and Bernard, H. (2003), "Techniques to identify themes", Field Methods, 15 (1), 85-109.

Schembri, S. (2006), "Rationalizing service logic, or understanding services as experience?" Marketing Theory, 6 (3), 381-92. 
Schmitt, B. (1999), “Experiential marketing”, Journal of Marketing Management, 15 (1-3), 53-67.

Seiders, K., G. Voss, D. Grewal and A. Godfrey (2005), "Do satisfied customers buy more? Examining moderating influences in a retailing context," Journal of Marketing, 69 (4), 26.

Shah, D., Rust, R., Parasuraman, A., Staelin, R. and Day, G. (2006), "The path to customer centricity", Journal of Service Research, Vol. 9 (2), 113-124.

Sharma, N. and Patterson, P. (1999), "The impact of communication effectiveness and service quality on relationship commitment in consumer, professional services," Journal of Services Marketing, 13 (2), 151.

Sharma, N. and Patterson, P. (2000), "Switching costs, alternative attractiveness and experience as moderators of relationship commitment in professional, consumer services," International Journal of Service Industry Management, 11 (5), 470.

Shaw, C. (2002), The DNA of customer experience: How emotions drive value. New York: Palgrave.

Spreng, R., Harrell, G. and Mackoy, R. (1995), 'Service recovery: Impact on satisfaction and intentions," Journal of Services Marketing, 9 (1), 15-23.

Srinivasan, S., Anderson, R. and Kishore, P. (1998), "Customer loyalty in e-commerce: An exploration of its antecedents and consequences," Journal of Retailing, 78 (1), 41-50.

Strauss, A. and Corbin, J. (1990), Basics of Qualitative Research: Grounded Theory Procedures and Techniques. Newbury Park, CA: Sage.

Sweeney, J., Soutar, G. and Johnson, L. (1999), "The role of perceived risk in the qualityvalue relationship: a study in a retail environment," Journal of Retailing, 75 (1), 77-105.

Tabachnick, B. and Fidell, L. (2001), Using Multivariate Statistics, 4th ed. New York: Harper-Collins.

Tax, S., Brown, S. and Chandrashekaran, M. (1998), "Consumer evaluations of service complaint experiences: implication for relationship marketing," Journal of Marketing, (62), 60-76.

Verhoef, P., Lemon, K., Parasuraman, A., Roggeveen, A., Schlesinger, L. and Tsiros, M. (2009), "Customer experience: Determinants, dynamics and management strategies," Journal of Retailing, 85 (1), 31-41.

Verhoef, P., Franses, P. and Hoekstra, J. (2002), "The effect of relational constructs on customer referrals and number of services purchased from a multiservice provider: does age of relationship matter?", Journal of the Academy of Marketing Science, Vol. 30 (3), 202 216.

Voss, C., Roth, A. V., and Chase, R. B. (2008), Experience, service operations strategy, and services as destinations: Foundations and exploratory investigation. Production and Operations Management, 17, 247-266. 
Voss, C. and Zomerdijk, L. (2007), "Innovation in experiential services - an empirical view," in Innovation in Services. London: DTI, 97-134.

Walsh, G. and Beatty, S. (2007), "Customer-based corporate reputation of the service firm: Scale development and validation," Journal of the Academy of Marketing Science, 35 (1), 127-43.

Watson, D., Clark, L., and Tellegen, A. (1988), Development and validation of brief measures of positive and negative affect: The PANAS scales. Journal of Personality and Social Psychology, 54, 1063-1070.

Yi, Y. (1990), "A Critical review of consumer satisfaction", in Review of Marketing, Vol. 4, V. Zeithaml, V. ed. Chicago, IL: American Marketing Association, 68-123.

Zeithaml, V., Berry, S. and Parasuraman, A. (1996), "The behavioral consequences of service quality," Journal of Marketing, 60 (2), 31-46.

Zeithaml, V., Parasuraman, A. and Malhotra, A. (2000), "E-service quality: Definition, dimensions and conceptual model," Marketing Science Institute Working Paper Series, Cambridge, MA.

Zeithaml, V. (1988), Consumer perceptions of price, quality, and value: A means-end model and synthesis of evidence. Journal of Marketing, 52, 2-22. 


\section{APPENDICES}

\section{APPENDIX A}

Measures of Study Constructs

EXQ

Respondents rated their customer experience on each scale item using a 7-point scale $(1=$ strongly disagree, 7 = strongly agree) with a Do not know/Not applicable option as additional option next to the scale. The items below are grouped by dimensions for expositional convenience; they appeared in random order on the survey. The symbols preceding the items correspond to the variables named in Figure 4.

Peace of mind

PEA1 I am confident in their expertise; they know what they are doing.

PEA2 The whole process was so easy, they took care of everything.

PEA3 It is not just about the now; this company will look after me for a long time.

PEA4 I am already a customer; they know me and take good care of me, so why should I go somewhere else?

PEA5 I have dealt with them before so getting a mortgage was really easy.

PEA6 I choose them because they give independent advice. 
Moments-of-truth

MOM1 It was important that the company was flexible in dealing with me and looking out for my needs.

MOM2 It is important that they keep me up-to-date and inform me about new options.

MOM3 I want to deal with a safe company, because a mortgage is a lot of money.

MOM4 It is important that the people I am dealing with are good people; they listen, are polite and make me feel comfortable.

MOM5 The way they deal(t) with me when things go(went) wrong will decide if I stay with them.

Outcome Focus

OUT1 Yes, there are other companies, but I would rather stay with mine; it makes the process much easier.

OUT2 It was more important to get the mortgage than to shop around for a better rate.

OUT3 I stay with my company because I am not confident about using an alternative provider.

OUT4 It was important that the advisor had a mortgage too; he/she knew what I was going through. 
Product Experience

PRO1 I want to choose between different options to make certain I get the best offer.

PRO2 It is important to me to receive mortgage offers from different companies.

PRO3 Unless I can compare different options, I will not know which one is the best for me.

PRO4 It would be great if I could deal with one designated contact through the entire process of getting my mortgage. 
Figure 1 Means end framework EXQ

\begin{tabular}{|c|c|c|}
\hline $\begin{array}{c}\text { Concrete } \\
\text { Attributes, } \\
\text { represented by } \\
\text { the items of } \\
\text { EXQ }\end{array}$ \\
Abstract \\
Attributes, i.e. \\
Dimensions of \\
EXQ
\end{tabular}$\Rightarrow$\begin{tabular}{c}
$\begin{array}{c}\text { Consequences } \\
\text { represented by } \\
\text { customer } \\
\text { outcomes, such } \\
\text { as customer } \\
\text { satisfaction, } \\
\text { loyalty and } \\
\text { WOM }\end{array}$ \\
\hline
\end{tabular}


Figure 2 Scale Development Process to Measure Service Experience

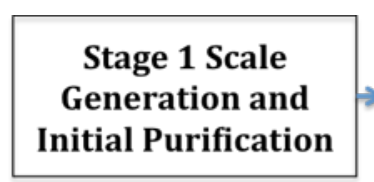

- Using insight from
literature review to
choose context
- In-depth interviews
(n=30)
- Generate initial pool
of items
-Readability Check
(n=10)
- Expert judgment
tasks to assess face
and construct validity
(n=7)
-Q-sorting ( 8
categories)
- Initial purification
and categorization
(a)n=7
(b)n=5
- Produced 37 items
in 5 dimensions for
next stage

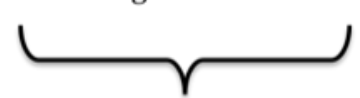

Qualitative Enquiry and Initial Purification
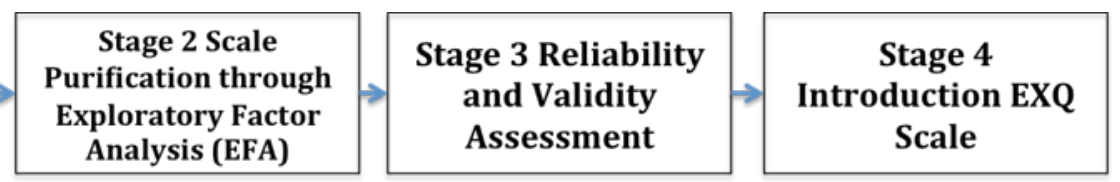

- Collect responses from representative sample $(\mathrm{n}=75)$ - Exploratory factor analysis (on 5-dimensional model)

- Assess content validity, scale reliability and validity - Develop purified scale with 19 items in four dimensions for next stage



\section{Purification and Refinement}

- Collect responses from additional representative sample $(\mathrm{n}=218)$ - Confirmatory factor analysis (on 4-dimensional model)

- Assess factor structure and dimensionality of scale

- Assess model fit -Assess scale and construct reliability and discriminant validity

- Final EXQ scale of 19 items in four dimensions
- Final EXQ scale of 19 items in four dimensions, conceptual model

\section{Final Refinement and Validation}


Figure 3 Service Experience Scale (EXQ) Items after Stage 1 of Scale Development

\begin{tabular}{|c|c|c|c|c|c|}
\hline Dimension & Process Experience & Product Experience & Lifetime Costs & Risk & Provider Experience \\
\hline Description & $\begin{array}{l}\text { Experiences } \\
\text { connected with the } \\
\text { process of securing } \\
\text { a mortgage }\end{array}$ & $\begin{array}{l}\text { Experience connected } \\
\text { with the range and } \\
\text { features of the provider's } \\
\text { services }\end{array}$ & $\begin{array}{l}\text { The total costs of } \\
\text { searching, } \\
\text { applying, securing } \\
\text { and paying for the } \\
\text { mortgage }\end{array}$ & $\begin{array}{l}\text { The perceived risk } \\
\text { of accepting a } \\
\text { significant } \\
\text { financial } \\
\text { obligation }\end{array}$ & $\begin{array}{l}\text { The customer's } \\
\text { assessment of all the } \\
\text { interactions with the } \\
\text { service provider } \\
\text { before, during and } \\
\text { after securing a } \\
\text { mortgage }\end{array}$ \\
\hline Scale Items & $\begin{array}{l}\text { Process ease } \\
\text { Process frustration } \\
\begin{array}{l}\text { Account } \\
\text { management }\end{array} \\
\begin{array}{l}\text { Multi-channel } \\
\text { experience }\end{array} \\
\text { Past experience }\end{array}$ & $\begin{array}{l}\text { Freedom of choice } \\
\text { Cross-product } \\
\text { comparison } \\
\text { Comparison } \\
\text { necessity/variety seekers } \\
\text { Product diversity } \\
\text { Additional offerings } \\
\begin{array}{l}\text { Not all my eggs in one } \\
\text { basket }\end{array}\end{array}$ & $\begin{array}{l}\text { Price sensitive } \\
\text { Interest rate } \\
\text { sensitivity } \\
\text { Best rate } \\
\text { True costs }\end{array}$ & $\begin{array}{l}\begin{array}{l}\text { Mortgage } \\
\text { millstone }\end{array} \\
\text { Emotional impact } \\
\text { of disclosure } \\
\text { Risk perception } \\
\text { Inertia }\end{array}$ & 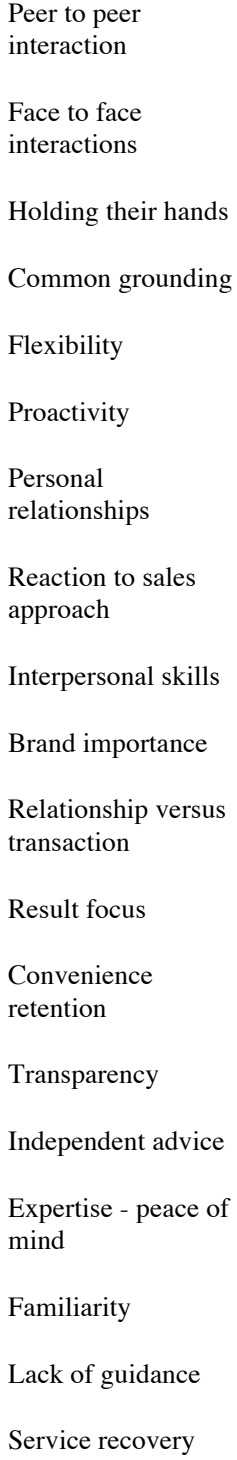 \\
\hline
\end{tabular}


Figure 4 Dimensions Service Experience Scale EXQ

\begin{tabular}{|c|c|c|c|}
\hline $\begin{array}{c}\text { PRODUCT } \\
\text { EXPERIENCE (PRO) }\end{array}$ & $\begin{array}{c}\text { OUTCOME FOCUS } \\
\text { (OUT) }\end{array}$ & $\begin{array}{l}\text { MOMENTS-OF- } \\
\text { TRUTH (MOM) }\end{array}$ & $\begin{array}{c}\text { PEACE-OF-MIND } \\
\text { (PEA) }\end{array}$ \\
\hline $\begin{array}{l}\text { PRO1 Freedom of } \\
\text { Choice }\end{array}$ & OUT1 Inertia & MOM1 Flexibility & $\begin{array}{l}\text { PEA1 Expertise - } \\
\text { Peace of Mind }\end{array}$ \\
\hline $\begin{array}{l}\text { PR02 Comparison } \\
\text { Necessity }\end{array}$ & OUT2 Result Focus & MOM2 Pro-activity & PEA2 Process Ease \\
\hline PR03 Cross-product & OUT3 Past & MOM3 Risk & PEA3 Relationship \\
\hline Comparison & $\begin{array}{l}\text { Experience } \\
\text { Influence }\end{array}$ & Perception & versus Transaction \\
\hline \multirow[t]{2}{*}{$\begin{array}{l}\text { PRO4 Account } \\
\text { Management }\end{array}$} & $\begin{array}{l}\text { OUT4 Common } \\
\text { Grounding }\end{array}$ & $\begin{array}{l}\text { MOM4 } \\
\text { Interpersonal Skills }\end{array}$ & $\begin{array}{l}\text { PEA4 Convenience } \\
\text { Retention }\end{array}$ \\
\hline & & $\begin{array}{l}\text { MOM5 Service } \\
\text { Recovery }\end{array}$ & $\begin{array}{l}\text { PEA5 Familiarity } \\
\text { PEA6 Independent } \\
\text { Advice }\end{array}$ \\
\hline
\end{tabular}


Figure 5 Service Experience Construct and Measure (EXQ)

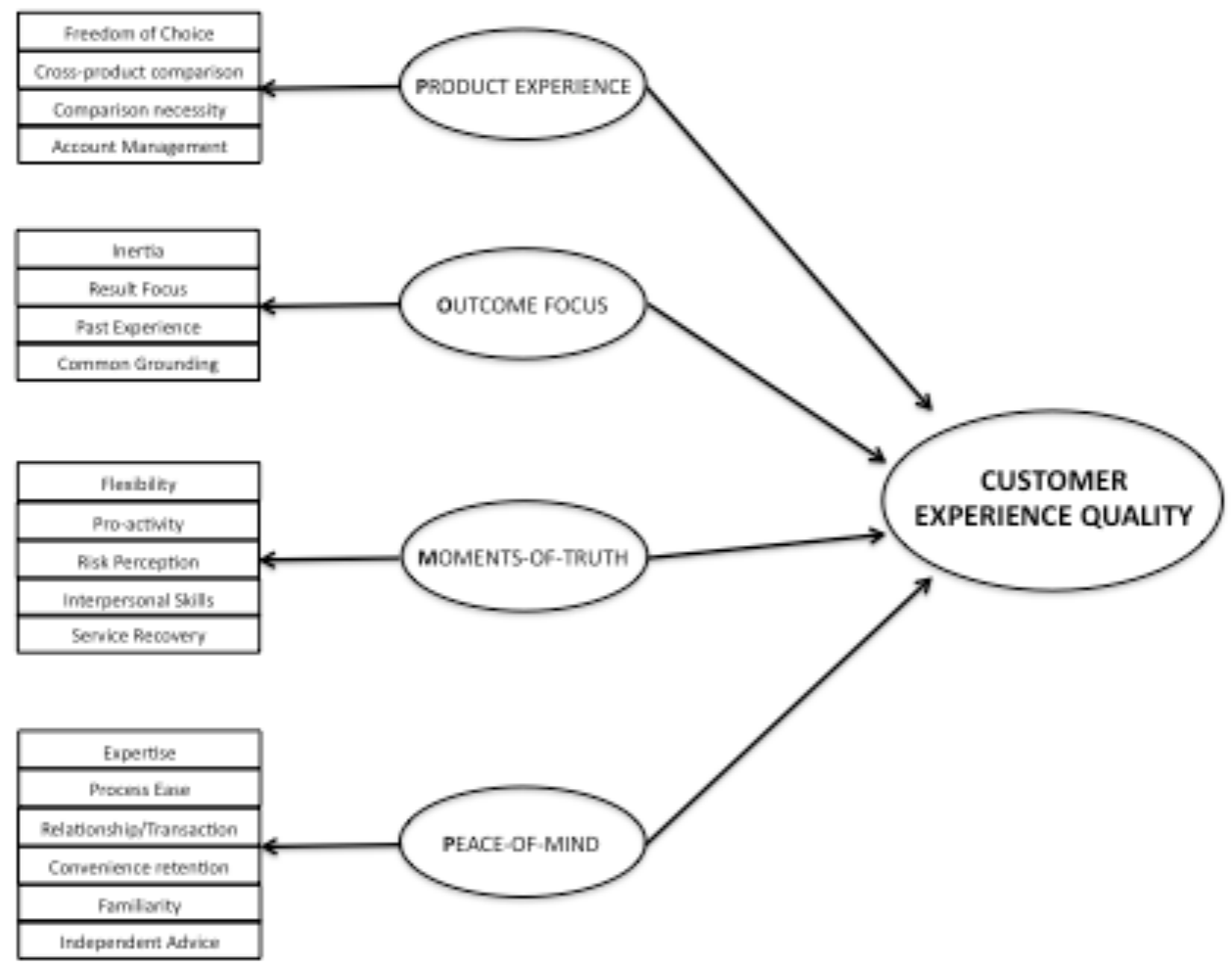


Table 1 Profile of the Two Samples

\begin{tabular}{|c|c|c|}
\hline Variable & Exploratory Study & Confirmatory Study \\
\hline Age in Years & Percentage & Percentage \\
\hline $18-25$ & 2.20 & 3.10 \\
\hline $26-35$ & 36.00 & 34.40 \\
\hline $36-45$ & 29.30 & 28.10 \\
\hline $46-55$ & 20.90 & 20.00 \\
\hline $56-64$ & 11.60 & 10.60 \\
\hline $65+$ & $\mathrm{NA}^{\mathrm{a}}$ & 3.80 \\
\hline \multicolumn{3}{|l|}{ Sex } \\
\hline Male & 64.00 & 60.20 \\
\hline Female & 46.00 & 39.80 \\
\hline \multicolumn{3}{|l|}{ Level of Education } \\
\hline High School or less & 31.90 & 36.00 \\
\hline Some College & 47.50 & 50.30 \\
\hline College Graduate & 12.80 & 12.40 \\
\hline Araduate School & 7.8 & 1.3 \\
\hline
\end{tabular}


Table 2 Measurement, Reliability, and Validity of the Service Experience Scale (EXQ)

\section{Measurement}

Model

Satisfaction

Loyalty intentions

Word-of-mouth

intentions

EXQ dimensions

Peace-of-mind

Moments-of-truth

Outcome focus

Product experience

Goodness-of-fit indices

Confirmatory sample
Construct Reliability

Confirmatory $(\mathrm{n}=218)$

0.94

0.84

0.96

0.90

0.80

0.83

0.81

0.75

0.75

0.71

0.80

0.79

$\begin{array}{lllll}\text { CMIN } & \text { df } & \text { CFI } & \text { IFI } & \text { RMSEA } \\ 711 & 392 & .91 & .91 & .05\end{array}$


Table 3 Construct Reliability Analysis

\begin{tabular}{|c|c|c|}
\hline Dimension & Item & Construct Reliability Score \\
\hline Peace-of-mind & PEA1 & .833 \\
\hline \multirow[t]{5}{*}{ (Composite Reliability.69) } & PEA2 & .678 \\
\hline & PEA3 & .631 \\
\hline & PEA4 & .422 \\
\hline & PEA5 & .548 \\
\hline & PEA6 & .358 \\
\hline \multirow[t]{5}{*}{ Moments-of-truth (.71) } & MOM1 & .669 \\
\hline & MOM2 & .652 \\
\hline & MOM3 & .568 \\
\hline & MOM4 & .522 \\
\hline & MOM5 & .484 \\
\hline \multirow[t]{4}{*}{ Outcome focus (.61) } & OUT1 & .477 \\
\hline & OUT2 & .518 \\
\hline & OUT3 & .695 \\
\hline & OUT4 & .455 \\
\hline \multirow[t]{4}{*}{ Product experience (.66) } & PRO1 & .744 \\
\hline & $\mathrm{PRO} 2$ & .744 \\
\hline & PRO3 & .841 \\
\hline & PRO4 & .500 \\
\hline
\end{tabular}


Table 4 Comparison of service experience and customer experience conceptual models

\begin{tabular}{|c|c|c|c|c|}
\hline \multicolumn{5}{|c|}{ Comparison of service experience and customer experience conceptual models } \\
\hline Model & EXQ (Klaus 2011) & $\begin{array}{l}\text { Customer } \\
\text { Experience } \\
\text { Creation (Verhoef } \\
\text { et al. 2009) }\end{array}$ & $\begin{array}{l}\text { Customer } \\
\text { Experience } \\
\text { (Gentile, Spiller } \\
\text { and Noci 2007) }\end{array}$ & $\begin{array}{l}\text { Customer } \\
\text { Experience } \\
\text { (Meyer and } \\
\text { Schwager 2007) }\end{array}$ \\
\hline Dimensions & $\begin{array}{l}\text { Peace-of-mind } \\
\text { Moments-of-truth } \\
\text { Result focus } \\
\text { Product } \\
\text { experience }\end{array}$ & $\begin{array}{l}\text { Social } \\
\text { Environment } \\
\text { Service Interface } \\
\text { Retail Atmosphere } \\
\text { Assortment } \\
\text { Price } \\
\text { Customer } \\
\text { experiences in } \\
\text { alternative } \\
\text { channels } \\
\text { Retail brand }\end{array}$ & $\begin{array}{l}\text { Sensorial } \\
\text { Emotional } \\
\text { Cognitive } \\
\text { Pragmatic } \\
\text { Lifestyle } \\
\text { Relational }\end{array}$ & Not available \\
\hline Methodology & $\begin{array}{l}\text { Empiricism, scale } \\
\text { development }\end{array}$ & Literature Review & $\begin{array}{l}\text { Empiricism, factor } \\
\text { analysis }\end{array}$ & $\begin{array}{l}\text { Case study based } \\
\text { on customer } \\
\text { survey } \\
\text { (anecdotal) }\end{array}$ \\
\hline $\begin{array}{l}\text { Exploratory } \\
\text { research conducted } \\
\text { to define construct }\end{array}$ & Yes & No & No & No \\
\hline $\begin{array}{l}\text { Establishing link } \\
\text { with important } \\
\text { marketing } \\
\text { outcomes } \\
\text { empirically }\end{array}$ & Yes & No & Yes & No \\
\hline $\begin{array}{l}\text { Outcomes } \\
\text { empirically linked } \\
\text { to construct }\end{array}$ & $\begin{array}{l}\text { Repurchasing } \\
\text { behavior } \\
\text { Customer } \\
\text { satisfaction } \\
\text { Stated loyalty } \\
\text { Positive word-of- } \\
\text { mouth intentions }\end{array}$ & Not available & $\begin{array}{l}\text { Customer } \\
\text { commitment } \\
\text { Customer } \\
\text { involvement }\end{array}$ & Not available \\
\hline
\end{tabular}

